\title{
Evidence supporting the safety of rapid refeeding protocols, using a food based approach, in a paediatric inpatient eating disorder program
}

\author{
Shea Edsall, Terrill Bruere*, Kellie Draffin, Amy Gregor \\ From 2013 ANZAED Conference: Inspiring Change: Person and Context \\ Melbourne, Australia. 23-24 August 2013
}

Historically, a cautious approach to refeeding has been taken due to lack of evidence about refeeding syndrome. The aim of this study was to evaluate outcomes following the introduction of a more aggressive feeding protocol in a paediatric eating disorder program. This included commencing at a higher energy intake, more rapid energy increases and macronutrient manipulation of meal plans while maintaining a food based approach.

A restrospective audit of 38 Austin Hospital patients admitted for medical stabilisation of their eating disorder, using rapid refeeding protocols, were compared to previous refeeeding protocols. Thirty-seven patients (97\%) were commenced on 8.2 megajoules (MJ) or more and increased to $11 \mathrm{MJ}$ within one week. Previously, 23 patients $(60 \%)$ had commenced on $6.8 \mathrm{MJ}$ or less. With more intensive feeding 30 patients $(79 \%)$ gained more than the target of 1 to 1.5 kilograms per week (compared to $35 \%$ previously). Evidence of refeeding syndrome was identified and treated in only two patients (5\%). Only one patient required a lower energy intake $(6.5 \mathrm{MJ})$ with reduced contribution to energy from carbohydrates (40\%) due to high risk of refeeding syndrome.

These findings suggest more rapid refeeding can be achieved safely with a food based approach in this patient group.

This abstract was presented in the Care in Inpatient and Community Settings stream of the 2013 ANZAED Conference.

Published: 14 November 2013

\footnotetext{
* Correspondence: Terrill.bruere@austin.org.au Austin Hospital Melbourne, Australia
}

(0) 2013 Edsall et al; licensee BioMed Central Ltd. This is an Open Access article distributed under the terms of the Creative Commons Attribution License (http://creativecommons.org/licenses/by/2.0), which permits unrestricted use, distribution, and reproduction in any medium, provided the original work is properly cited.
doi:10.1186/2050-2974-1-S1-017

Cite this article as: Edsall et al: Evidence supporting the safety of rapid refeeding protocols, using a food based approach, in a paediatric inpatient eating disorder program. Journal of Eating Disorders 20131 (Suppl 1):017.
Submit your next manuscript to BioMed Central and take full advantage of:

- Convenient online submission

- Thorough peer review

- No space constraints or color figure charges

- Immediate publication on acceptance

- Inclusion in PubMed, CAS, Scopus and Google Scholar

- Research which is freely available for redistribution
C Biomed Central 